\title{
Home range and diving behaviour of Heaviside's dolphins monitored by satellite off the west coast of South Africa
}

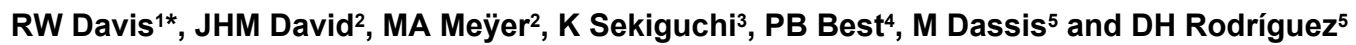 \\ ${ }^{1}$ Department of Marine Biology, Texas A\&M University, Galveston, USA \\ 2 Branch: Oceans and Coasts, Department of Environmental Affairs, Cape Town, South Africa \\ ${ }^{3}$ International Christian University, Mitaka-shi, Tokyo, Japan \\ ${ }^{4}$ Mammal Research Institute, University of Pretoria, c/o Iziko South African Museum, Cape Town, South Africa \\ ${ }^{5}$ Instituto de Investigaciones Marinas y Costeras, Facultad de Ciencias Exactas y Naturales, Universidad Nacional de Mar \\ del Plata - CONICET, Mar del Plata, Argentina \\ *Corresponding author, e-mail: davisr@tamug.edu
}

\begin{abstract}
Three Heaviside's dolphins Cephalorhynchus heavisidii were fitted with satellite depth recorders off the west coast of South Africa during February-April 1997 and monitored for 51, 73 and 130 days, respectively. In total, 345 locations were received from the three animals, but only 27 from one male. Using $\alpha$-local convex hull and minimum convex polygon methods, respectively, the home range for the remaining male was estimated at 1520 and $2347 \mathrm{~km}^{2}$, with corresponding corearea estimates $\left(50 \%\right.$ of locations) of 134 and $123 \mathrm{~km}^{2}$. For the female, the home range estimates were 672 and $1027 \mathrm{~km}^{2}$, and those for the core area were 71 and $230 \mathrm{~km}^{2}$. The female's home range was the smallest yet described for this species, and the animal was resighted nearly three years later within $13 \mathrm{~km}$ of the tagging site. Binned dive data were received at 6-hourly intervals. From comparison of maximum dive depth and time-at-depth data, we concluded that dives <4 $\mathrm{m}$ deep were associated with surfacing bouts. Dives to below $4 \mathrm{~m}$ occurred throughout $24 \mathrm{~h}$ but were shallower during the day and deepest either at dusk or at night. This pattern was consistent with earlier descriptions of offshore movement during the day and may be related to the diel vertical migration of its principal prey, shallow-water hake Merluccius capensis.
\end{abstract}

Keywords: Cephalorhynchus heavisidii, dive depth, saddle attachment, Service Argos satellite system, surfacing intervals, time-at-depth

\section{Introduction}

Heaviside's dolphin Cephalorhynchus heavisidii is a small (maximum length $1.75 \mathrm{~m}$ ) delphinid that occurs only in southern Africa. Its range is limited to the cool Benguela Current off south-western Africa from Cape Point (34 $21^{\prime} \mathrm{S}$ ) northward to at least southern Angola (16³0' S; Best 2007) and in coastal waters over the continental shelf (Findlay et al. 1992; Best and Abernethy 1994) where it is generally encountered in water $<100 \mathrm{~m}$ deep. It occurs in small schools of $<10$ animals, and in the Western Cape seems to show a distinct diel pattern of movement, being closest inshore in the early morning (when it favours areas of high wave energy) and farthest offshore around midnight (Elwen et al. 2006, 2009). Seasonal movements have not been described, and although births generally occur in summer the breeding season may be protracted (Best 2007). Its prey in the region consists largely of benthic and demersal organisms such as shallow-water hake Merluccius capensis and kingklip Genypterus capensis, as well as cephalopods, especially an octopus species ${ }^{1}$ (Sekiguchi et al.1992). Not only does the species' distribution overlap several important commercial fisheries off the West Coast (Crawford et al. 1987), but its nearshore habitat and limited-range sonar put it at risk of entanglement in gill- and other setnets in the

\footnotetext{
${ }_{1}^{1}$ Probably either Octopus vulgaris or Enteroctopus magnificus (N Klages, Gibb (Pty) Ltd, Port Elizabeth, South Africa, pers. comm.)
}

region (Best 2007). Its conservation status is listed as Data Deficient (Reeves et al. 2013).

In view of the potential hazards in its environment, information on how Heaviside's dolphin utilises its habitat could be of considerable importance to its conservation. We therefore studied the movements, diving behaviour and habitat associations of three Heaviside's dolphins along the west coast of South Africa for 51, 73 and 130 days, respectively, during 1997 using satellite telemetry. This project preceded that of Elwen et al. (2006), but differs in including home-range data for a male and diving behaviour for both sexes.

\section{Material and methods}

Dolphins were captured from a bow pulpit on the $21.6 \mathrm{~m} \mathrm{RV}$ Malagas II using a breakaway hoopnet (Asper 1975) with buoy attached. The buoy, capture line and dolphin were retrieved by divers in an inflatable skiff riding astern of the ship. Aboard the Malagas II, the animal was weighed, sexed, and its respiration monitored by a veterinarian. Judging by the lengths and body masses of the three animals captured (Table 1), H1, a male, was probably sexually immature, $\mathrm{H} 2$, also a male, was probably sexually mature and $\mathrm{H} 3$, a female, was also probably sexually mature (Best 2007). Two animals were freezebranded $(\mathrm{H} 2$ and $\mathrm{H} 3)$ on both sides at the base of the dorsal 
Table 1: Details of deployment of satellite tags on three Heaviside's dolphins ( $\mathrm{H} 1, \mathrm{H} 2$ and $\mathrm{H} 3)$ off the west coast of South Africa

\begin{tabular}{|c|c|c|c|}
\hline Parameter & Dolphin $\mathrm{H} 1$ & Dolphin H2 & Dolphin H3 \\
\hline Sex & Male & Male & Female \\
\hline Mass (kg) & 58.0 & 68.5 & 63.5 \\
\hline Date and time captured & 18 February $1997,17: 57$ & 20 February $1997,12: 28$ & 19 April 1997, 18:23 \\
\hline Capture position & $32^{\circ} 22.59^{\prime} \mathrm{S}, 18^{\circ} 18.99^{\prime} \mathrm{E}$ & $32^{\circ} 25.86^{\prime} \mathrm{S}, 18^{\circ} 19.76^{\prime} \mathrm{E}$ & $32^{\circ} 19.34^{\prime} \mathrm{S}, 18^{\circ} 18.36^{\prime} \mathrm{E}$ \\
\hline Last transmission & 9 April 1997, 04:52 & 29 June 1997, 01:15 & 30 June $1997,11: 46$ \\
\hline Total locations received & 134 & 27 & 184 \\
\hline Class Z locations & 1 & 0 & 3 \\
\hline Clearly wrong locations & 1 & 3 & 2 \\
\hline Horizontal speed $>4 \mathrm{~m} \mathrm{~s}^{-1}$ & 5 & 7 & 37 \\
\hline Locations on land & 9 & 3 & 16 \\
\hline Total discarded & 16 & 13 & 58 \\
\hline
\end{tabular}

fin (Odell and Asper 1990), and for each animal a suite of morphometrics and photographs were taken, a colour-coded tag fitted, samples of skin, blood and blow collected, heart rate monitored and a tooth extracted (except in H3), after which the animal was released near its capture site within $95 \mathrm{~min}$.

Each dolphin was fitted with a Type 3 satellite depth recorder (SDR) manufactured by Wildlife Computers (Redmond, Washington) and mounted in a dorsal fin saddle. The SDR $(110 \mathrm{~mm} \times 90 \mathrm{~mm} \times 25 \mathrm{~mm})$ consisted of a resinencased platform terminal transmitter (PTT), electronics that monitored and stored data on diving behaviour, a pressure transducer, batteries and a $100 \mathrm{~mm}$ flexible antenna. Each of the first two dolphins was also fitted with a small $(60 \mathrm{~mm} \times$ $28 \mathrm{~mm}$ ) VHF transmitter with a $220 \mathrm{~mm}$ flexible antenna (SIRTRACK, Havelock North, New Zealand). The transmitters broadcast at $148 \mathrm{MHz}$ at a rate of 100 pulses min $^{-1}$ and with a power output of $160 \mu \mathrm{W}$, and surfacing intervals were monitored using a VHF receiver aboard the capture vessel.

Polyethylene thermoplastic dorsal fin saddles (TracPac ${ }^{\mathrm{TM}}$ Inc., Fort Walton Beach, Florida) were fabricated based on the fibreglass cast of a Heaviside's dolphin dorsal fin and lined with neoprene rubber (Davis et al. 1996). The hydrodynamic shape of the saddle reduced drag-induced force on the dorsal fin which can cause tissue damage (Irvine et al. 1982; Tanaka et al. 1987). The completed saddle measured $253 \mathrm{~mm} \times$ $46 \mathrm{~mm} \times 118 \mathrm{~mm}$. Moulded compartments along the sides held the SDR and VHF radio. The saddle with instrumentation weighed $625 \mathrm{~g}$ in air and was positively buoyant.

The saddle was attached to the dorsal fin with Delrin pins (Cadillac Plastic and Chemical Company, Houston, Texas) guided through $6.4 \mathrm{~mm}$ diameter holes cored through the fin. The coring device and pins were disinfected prior to use. The Delrin pins were held in place with magnesium nuts (Metal Supply Co., Philadelphia, Pennsylvania), designed to dissolve in about eight weeks when immersed in sea water at $13{ }^{\circ} \mathrm{C}$, thus releasing the saddle.

The maximum depth ranges for the SDRs (as set by the manufacturer) were $124 \mathrm{~m}(\mathrm{H} 1), 117 \mathrm{~m}(\mathrm{H} 2)$ and $233 \mathrm{~m}$ $(\mathrm{H} 3)$, with a resolution of $0.5 \mathrm{~m}$ for the first two and $1 \mathrm{~m}$ for the third. Depths were recorded every $10 \mathrm{~s}$, and a dolphin had to submerge below $2 \mathrm{~m}$ for at least $10 \mathrm{~s}$ for the event to be logged as a 'dive'. Data on maximum dive depths, dive durations, and the amount of time that the animal spent at certain depths, were recorded and encoded into histograms with programmable ranges of depth and time. The maximum depth of each dive was logged as either 2-4, 4-10, 10-20, $20-30,30-40,40-50,50-60,60-70,70-80$ or $>80 \mathrm{~m}$ (the shallowest interval for the first depth bin being automatically set by the minimum cut-off point for registering a dive). These bins were chosen on the basis that the species normally occurs in water depths of $<100 \mathrm{~m}$ (Best and Abernethy 1994). Each dive was logged as either 0-1, 1-2, 2-3, 3-4, $4-5,5-6,6-7,7-8,8-9$ or $>9$ min in duration, and the bins used to record the time spent at depth were 0-2, 2-4, 4-10, $10-20,20-30,30-40,40-50,50-60,60-70$ or $>70 \mathrm{~m}$. The transmit buffer stored $24 \mathrm{~h}$ of data in 6-hourly histogram periods that corresponded to night (period 0; 21:00-02:59 local time), dawn (period 1; 03:00-08:59 local time), day (period 2; 09:00-14:59 local time) and dusk (period 3; 15:00-20:59 local time). Contemporary local times of sunrise and sunset ranged from 06:24-07:52 and 17:47-19:35, respectively. Limitations to the data collection were that (1) all individual bins were capped at 255 data points per period, and (2) time-at-depth histograms for each 6-hourly period were compressed using a common denominator of 2160 (the number of $10 \mathrm{~s}$ intervals in a period) to optimise the amount of data for transmission. The SDRs had a salt water switch so that a message was transmitted only when at the surface, and they were programmed to transmit a maximum of 300 messages $\mathrm{d}^{-1}$. The minimum interval between transmissions was $40 \mathrm{~s}$ for $\mathrm{H} 1$ and $\mathrm{H} 2$, and $20 \mathrm{~s}$ for $\mathrm{H} 3$.

The Service Argos satellite system with two satellites operating (Satellite D and Satellite J) was used to track the dolphins and receive dive data via messages transmitted by the SDRs (for a detailed description of the Argos system see Mate [1989], Mate et al. [1992] and Stewart et al. [1989]). The mean orbital period for a satellite was about $100 \mathrm{~min}$, during which the SDR (if at the surface) was in view of the satellite for c. 4-15 min. During this short time, at least three messages had to be received by the satellite for a location to be calculated accurately. Service Argos classifies locations according to their accuracy as Class 3 error $<150 \mathrm{~m}$; Class 2 
error $<350 \mathrm{~m}$; Class 1 error $<1 \mathrm{~km}$; Class 0 error $>1 \mathrm{~km}$; Class A and Class B - no predictions for the estimations of accuracy. Calibration studies have generally confirmed the accuracy of Argos locations (although errors may be greater in longitude than latitude), and have recommended the use of Class A and B (and sometimes Class 0 ) locations (Vincent et al. 2002; White and Sjoberg 2002; Witt et al. 2010), in addition to Classes 1-3. No coordinates were supplied for Class $Z$ locations, which were not used in this study.

Locations were plotted using Surfer 7.0 (Golden Software Inc., Golden, Colorado). Coastline and bathymetric data were provided by the South African Naval Hydrographic Office (Chart SAN 55) on a 5' latitude/longitude basis. The water depth at each dolphin location (after culling - see below) was derived from the mean depth for the $5^{\prime}$ square in which that location fell, and their occurrence binned by $20 \mathrm{~m}$ depth intervals.

Transit speeds (distance between each location divided by the time elapsed) were calculated, but because of the infrequency of locations received, were considered of dubious biological significance and were used only in culling location data (see Table 1).

For home-range analysis, the data were sorted for (a) obviously incorrect locations, including those over land, and (b) locations involving transit speeds $>4 \mathrm{~m} \mathrm{~s}^{-1}$ : the latter was chosen as a cut-off point based on the distribution of maximum speeds of free-ranging delphinids (Rohr et al. 2002) (Table 1). Points falling squarely on the coastline were considered to be at sea.

Home ranges of each animal were estimated by minimum convex polygon (MCP; Mohr 1947), and $\alpha$-local convex hull methods (LoCoH; Getz and Wilmers 2004) using the CALHOME software (Kie et al. 1996) and the local convex hull home range generator extension (http://nature.berkeley. edu/ ajlyons/locoh/av3x/index.html) for ArcView 3.2 GIS (ArcView 3.2; Environmental System Research Institute, ESRI, California), respectively. Although the MCP method is very sensitive to location inaccuracies and tends to overestimate home range (Burgman and Fox 2003), it has been included here for comparison with published estimates (Elwen et al. 2006). For kernel-based methods such as LoCoH, a minimum of 30 (or preferably $\geq 50$ ) observations per individual has been suggested (Seaman et al. 1999), so one dolphin $(\mathrm{H} 2)$ was excluded from this analysis.

Both methods were used to estimate total home range (using all locations) and core areas (the smallest areas enclosing $50 \%$ of all locations). $\mathrm{LoCoH}$ methods were also used to describe internal use of home ranges by constructing $30-90 \%$ isopleths (at $10 \%$ intervals). Home ranges were integrated in GIS to identify overlap areas between individuals. Locations and home ranges were plotted using the universal transverse mercator (UTM) coordinate system.

\section{Results}

The three dolphins were monitored for 51,73 and 130 days, respectively, and a total of 345 locations were received for all three (Table 1), of which four were Class $Z$. The remaining locations are plotted according to location class in Figure 1, except for two land locations (one each for $\mathrm{H} 2$ and $\mathrm{H} 3$ ) that fell outside the plotting range.

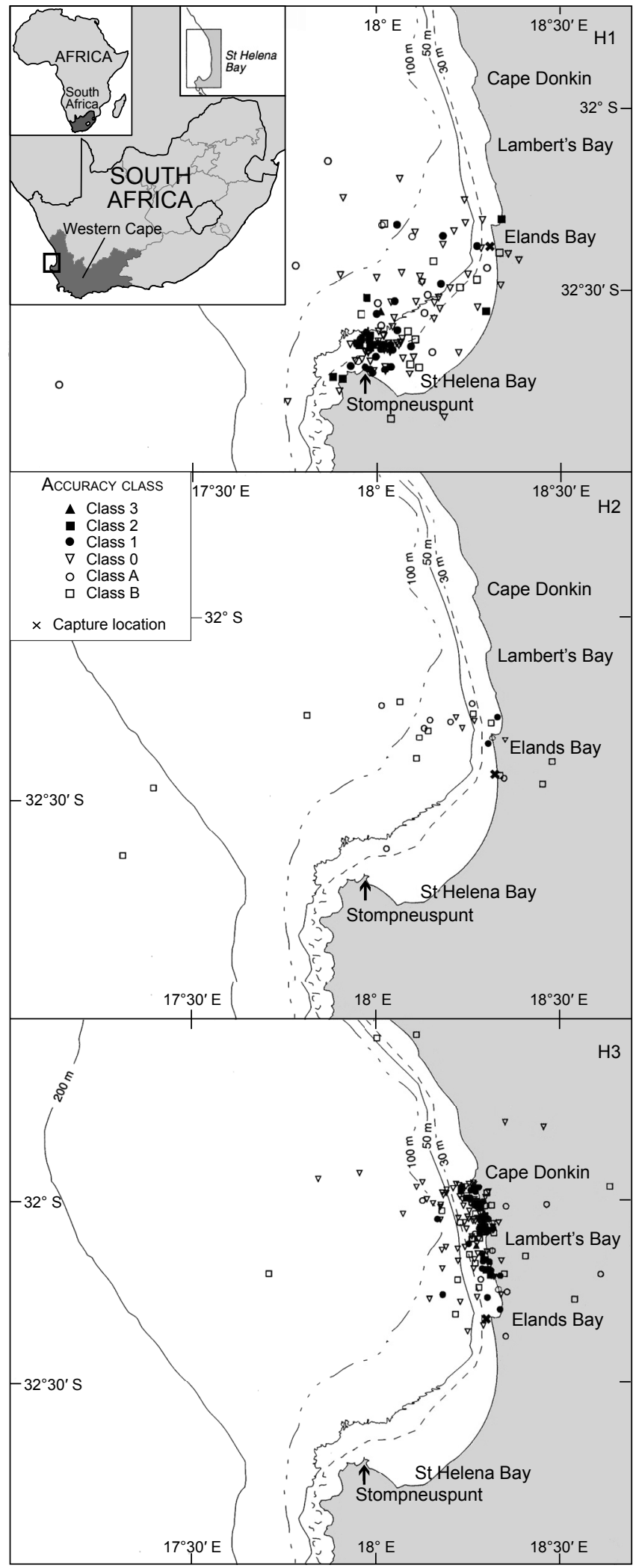

Figure 1: Locations received via satellite from three tagged Heaviside's dolphins $(\mathrm{H} 1, \mathrm{H} 2$ and $\mathrm{H} 3)$ off the west coast of South Africa (see inset for location of study area). Symbols refer to Argos accuracy classes 
There was a marked difference in the number and quality of satellite locations received for $\mathrm{H} 2$. Whereas locations were received on $98 \%$ of days for $\mathrm{H} 1$ and $94.5 \%$ of days for $\mathrm{H} 3$, positions for $\mathrm{H} 2$ were received on only $22(16.9 \%)$ of 130 days (once in both February and March, seven days in April, two days in May and 11 days in June). The quality of locations received for $\mathrm{H} 2$ was also significantly poorer, with classes $\mathrm{A}$ and $\mathrm{B}$ combined being $78 \%$ compared to $21 \%$ and $23 \%$ for $\mathrm{H} 1$ and $\mathrm{H} 3$, respectively $(\mathrm{H} 1+\mathrm{H} 3$ vs $\mathrm{H} 2$; $\chi^{2}$ (Yates correction $\left.)=18.95, p<0.001\right)$. The reason for this difference was unknown (see Discussion).

The locations were not received evenly throughout the day, with $94.1 \%$ being received during the night (138 locations) and at dawn (182 locations). Of the night-time positions, only $3.6 \%$ were received in the $3 \mathrm{~h}$ period before midnight, and the remaining $96.4 \%$ in the $3 \mathrm{~h}$ from 24:00 to $03: 00$. Hence, nearly all locations (92.6\%) were received between 24:00 and 09:00. This pattern was most marked for $\mathrm{H} 1$ (99.3\% locations) and $\mathrm{H} 3$ (93.3\% of locations), but even for $\mathrm{H} 2,74.1 \%$ of 27 locations were received between 22:00 and 7:00.

\section{Distribution and home range}

The three dolphins remained in the area between St Helena Bay and Cape Donkin, and most locations were close to the coast (Figure 1). The average distance from the closest land was $9.5 \mathrm{~km}$ (SE 0.7) for $\mathrm{H} 1$ ( $n=118$, range $0.1-32.9 \mathrm{~km})$, $16.2 \mathrm{~km}$ (SE 2.8) for $\mathrm{H} 2(n=14$, range $0.6-32 \mathrm{~km})$ and $4.7 \mathrm{~km}$ (SE 0.45) for $\mathrm{H} 3$ ( $n=121$, range $0-22.8 \mathrm{~km}$ ).

Total home range and core area sizes estimated according to $\alpha$-LoCoH and MCP methods indicated a bigger home range for $\mathrm{H} 1$ (1 500-2 $300 \mathrm{~km}^{2}$ ) than for $\mathrm{H} 3$ (670-1 $000 \mathrm{~km}^{2}$ ), although $\mathrm{H} 1$ tended to concentrate its activity in a smaller core area representing $5-9 \%$ of total home range, depending on the estimation method (Table 2, Figure 2). On the other hand, $\mathrm{H} 3$ used its home range more evenly with a larger core area of $10-22 \%$ of total home range.

Consistent with the depth analysis (see below), the core areas for $\mathrm{H} 1$ and $\mathrm{H} 3$ were located between the coastline and the $50 \mathrm{~m}$ isobath (Figure 2). Although estimates of core area were highly consistent between methods for $\mathrm{H} 1$, those for $\mathrm{H} 3$ were partitioned into two particular core areas in the $\alpha$ - $\mathrm{LoCoH}$ analyses and were thus smaller than in the MCP analysis, which by definition is incapable of subdivision (Figure 2).

The overlap area between $\mathrm{H} 1$ and $\mathrm{H} 3$ total home ranges was $122 \mathrm{~km}^{2}$ using the MCP method, representing $3.8 \%$ of the total area occupied by both animals; however, as the MCP method tends to overestimate home range, this figure is probably too high. Overlap areas from $\alpha-\mathrm{LoCoH}$ home ranges were detected only at $100 \%$ isopleths (as $1.4 \%$ of total home range) with no overlap at isopleths $\leq 90 \%$. There was no overlap region between core areas for any of the methods used. Although these animals could have occasional encounters, the results suggested a very low degree of overlap between them.

All three dolphins were most frequently located in the shallowest $(<20 \mathrm{~m}$ ) depth interval (Table 3). The data for $\mathrm{H} 2$ were too few $(n=14)$ for a more detailed analysis, but the distributions of locations for the other two were significantly

different, with $\mathrm{H} 3$ generally occurring in shallower water than $\mathrm{H} 1\left(\chi^{2}=32.74, p<0.0001,4 \mathrm{df}\right)$. Maximum recorded water depths were $127 \mathrm{~m}, 147 \mathrm{~m}$ and $122 \mathrm{~m}$ for $\mathrm{H} 1, \mathrm{H} 2$ and $\mathrm{H} 3$, respectively.

\section{Surfacing intervals}

Six days after the release of $\mathrm{H} 2$, it was seen with another dolphin leaving the breaker line and moving offshore to a water depth of $12 \mathrm{~m}$, where $25 \mathrm{~min}$ of surfacing-interval data were collected during a dedicated focal follow using received VHF transmissions. The dolphins moved slightly offshore in an erratic manner. A second opportunity to monitor $\mathrm{H} 2$ occurred 26 days later, for a period of 104 min. Combining the two samples, the mean interval between 166 surfacings was $47 \mathrm{~s}$ (range 6-526 s). The duration of surfacings was estimated at $0.6-1.8 \mathrm{~s}$, because only 1-3 signals were received per surfacing, at a transmission rate of 100 pulses min $^{-1}$.

The longer session took place at dusk (16:24-18:08 local time) and finished 44 min before sunset. There was a marked change in the dolphin's surfacing behaviour over this period, in that both the mean interval between surfacings and its associated CV progressively increased as sunset approached (Figure 3, Table 4).

\section{Diving behaviour}

Overall, the three dolphins made a similar number of dives (below $2 \mathrm{~m}$ ) per 6-h period, with averages of 186 (SE $4 ; n=$ 141), 194 (SE 9; $n=28$ ), and 190 (SE 3; $n=171$ ), respectively (one-way ANOVA, $F=0.55$, df $=2, p=0.5774$ ). The majority of these dives were very short: $61.0 \%, 68.6 \%$ and $47.9 \%$ of dives for $\mathrm{H} 1$ ( $n=26234), \mathrm{H} 2(n=5428)$ and $\mathrm{H} 3$ $(n=32509)$, respectively, were less than $1 \mathrm{~min}$ in duration, and $88.1 \%, 90.9 \%$ and $86.7 \%$, respectively, of dives were shorter than 2 min (Figure 4). Very few (only 1.7\%, 2.2\% and $0.9 \%$, respectively) were longer than $3 \mathrm{~min}$, and only $16(0.02 \%)$ exceeded $9 \mathrm{~min}$ for all three animals. Over a $24 \mathrm{~h}$ period, the most-frequented depth range by the three dolphins was that near the surface $(0-2 \mathrm{~m})$, where they spent $45.9 \%, 51.2 \%$ and $38.2 \%$ of their time, respectively

Table 2: Home range sizes ${ }^{1}$ and isopleths estimated for Heaviside's dolphins $\mathrm{H} 1$ and $\mathrm{H} 3$ using $\alpha$-local convex hull ( $\alpha$-LoCoH) and minimum convex polygon (MCP) methods

\begin{tabular}{|c|c|c|c|c|}
\hline \multirow[b]{2}{*}{$\begin{array}{l}\text { Method and } \\
\text { isopleth }\end{array}$} & \multicolumn{2}{|c|}{$\mathrm{H} 1$ home range $\left(\mathrm{km}^{2}\right)$} & \multicolumn{2}{|c|}{$\mathrm{H} 3$ home range $\left(\mathrm{km}^{2}\right)$} \\
\hline & $\begin{array}{c}\alpha \text {-LoCoH } \\
(\alpha=76000)\end{array}$ & MCP & $\begin{array}{c}\alpha \text {-LoCoH } \\
(\alpha=55000)\end{array}$ & MCP \\
\hline $\begin{array}{l}100 \% \text { (total } \\
\text { home range) }\end{array}$ & 1520 & 2347 & 672 & 1027 \\
\hline $90 \%$ & 783 & & 316 & \\
\hline $80 \%$ & 485 & & 193 & \\
\hline $70 \%$ & 371 & & 101 & \\
\hline $60 \%$ & 204 & & 101 & \\
\hline $50 \%$ (core area) & 134 & 123 & 71 & 230 \\
\hline $40 \%$ & 63 & & 39 & \\
\hline $30 \%$ & 36 & & 39 & \\
\hline $\begin{array}{l}\text { Core area as \% } \\
\text { of home range }\end{array}$ & 8.8 & 5.2 & 10.5 & 22.4 \\
\hline
\end{tabular}


(Figure 4). Most dives were shallow. When averaged over a $24 \mathrm{~h}$ period, $56.1 \%, 53.9 \%$ and $53.2 \%$ of the dives were $<10 \mathrm{~m}$ deep, and $97.9 \%, 98.9 \%$ and $97.4 \%$ were $<50 \mathrm{~m}$ deep for $\mathrm{H} 1$ ( $n=24$ 082), $\mathrm{H} 2(n=6490)$ and $\mathrm{H} 3(n=$ 31 837), respectively (Figure 4). The deepest dives for all three dolphins were $>80 \mathrm{~m}$, although $\mathrm{H} 3$ made only three such dives, whereas $\mathrm{H} 1$ and $\mathrm{H} 2$ made 136 dives $(0.6 \%)$ and 18 dives $(0.3 \%)$, respectively, to over $80 \mathrm{~m}$.

When comparing the numbers of dives to a particular depth stratum and the proportion of time spent at that depth, the pattern showed a similar feature in all three dolphins, in that the proportion of dives in the 2-4 $\mathrm{m}$

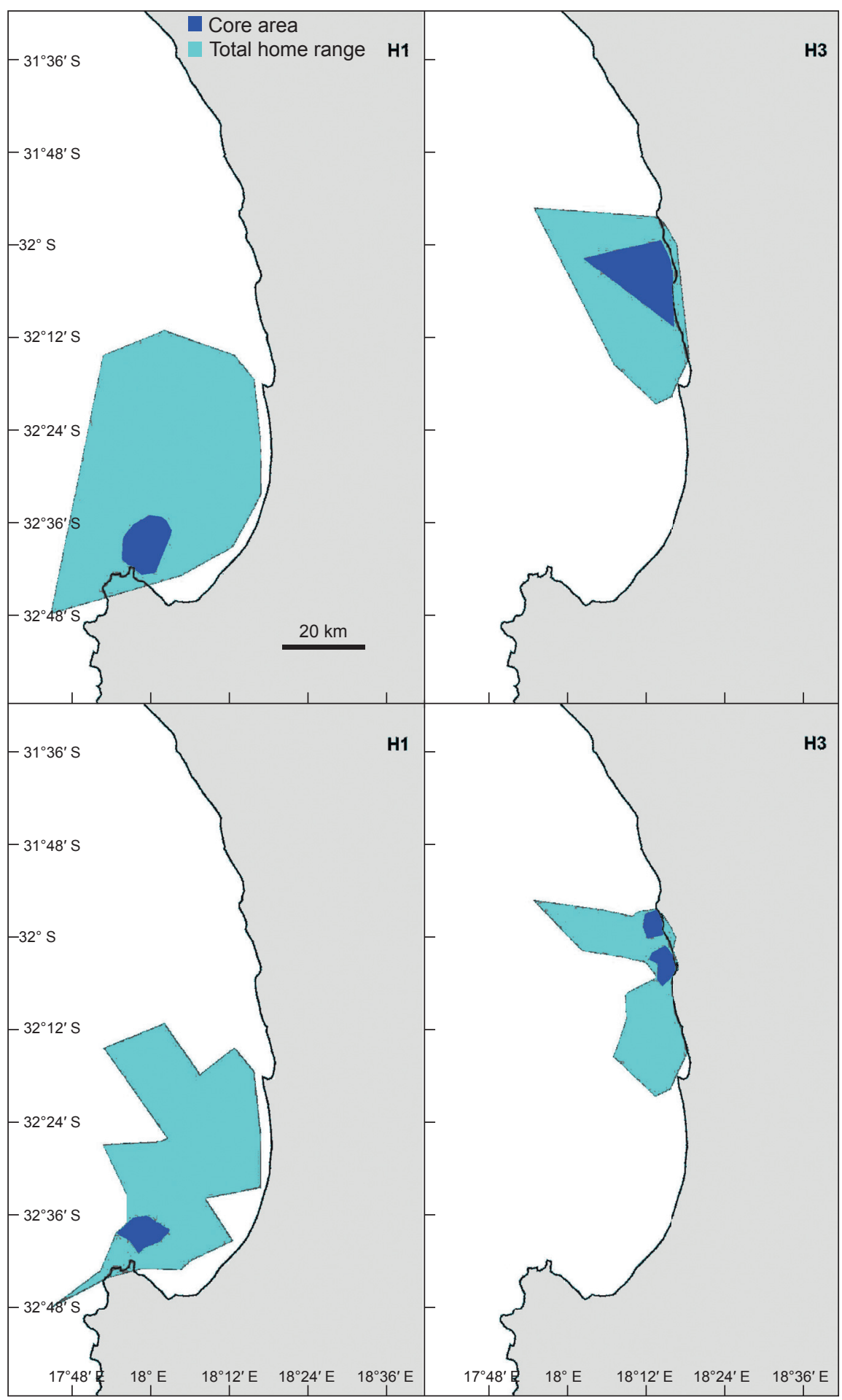

Figure 2: Total home range and core area of Heaviside's dolphins $\mathrm{H} 1$ and $\mathrm{H} 3$ estimated by the MCP method (upper) and the $\alpha$-LoCoH method (lower). Core areas enclose $50 \%$ of locations 
stratum greatly exceeded the proportion of time the dolphin spent there (by a factor of 1.97 in $\mathrm{H} 1,1.96$ in $\mathrm{H} 2$ and 3.23 in $\mathrm{H} 3$ ), whereas in all other strata the proportion of time spent there was greater than or equivalent to the relative number of dives to that stratum (Figure 5). This suggests that the majority of dives to $<4 \mathrm{~m}$ were of very short duration and could be attributed to part of a surfacing sequence. Consequently, $4 \mathrm{~m}$ was considered to be the dividing line

Table 3: Percentage of locations falling within various water depth intervals for three Heaviside's dolphins satellite-tagged off the west coast of South Africa

\begin{tabular}{lccc} 
& \multicolumn{3}{c}{ Percentage } \\
\cline { 2 - 4 } Depth $(\mathrm{m})$ & $\mathrm{H} 1$ & $\mathrm{H} 2$ & $\mathrm{H} 3$ \\
& $(n=118)$ & $(n=14)$ & $(n=124)$ \\
\hline$<20$ & 47.5 & 35.7 & 75.0 \\
$20-40$ & 29.7 & 7.1 & 7.3 \\
$40-60$ & 11.9 & 0 & 2.4 \\
$60-80$ & 3.4 & 21.4 & 4.0 \\
$80-100$ & 3.4 & 14.3 & 8.1 \\
$100-120$ & 3.4 & 14.3 & 2.4 \\
$120-140$ & 0.8 & 0 & 0.8 \\
$140-160$ & 0 & 7.1 & 0 \\
\hline Mean depth (SE) & $29.4(2.5)$ & $59.2(13)$ & $20.1(3)$ \\
Range of depths & $1-126.9$ & $2.3-147.1$ & $1-122.3$
\end{tabular}

between surfacing bouts and deeper dives and, therefore, a better distinction than the arbitrary $2 \mathrm{~m}$ chosen when setting up the tags. Hereafter, we refer to all submergences below $4 \mathrm{~m}$ as 'deep dives' to avoid confusion with the earlier designation.

Deep dives constituted $46.8 \%, 41.6 \%$ and $55.2 \%$ of the time spent each day for dolphins $\mathrm{H} 1$ to $\mathrm{H} 3$, respectively. The frequency of deep dives varied with 6-hourly period. For $\mathrm{H} 1$, the frequency of such dives was lowest during the day and highest at night, whereas their frequency for $\mathrm{H} 3$ was highest at dawn or during the day and lowest at dusk or during the night, the differences being statistically significant in both dolphins (Table 5). The maximum depths of deep dives also varied with time period. Assigning median values to each bin (e.g. $7 \mathrm{~m}$ for 4-10 m, $15 \mathrm{~m}$ for $10-20 \mathrm{~m}$, and $85 \mathrm{~m}$ for $>80 \mathrm{~m}$ ), the mean maximum depths reached were least during the day and greatest at dusk $(\mathrm{H} 1)$ or night $(\mathrm{H} 3)$, the difference being significant in both dolphins (Table 5).

The time spent on deeper dives varied with 6-hourly period for both dolphins. For $\mathrm{H} 1$, deeper dives comprised $40.0 \%, 40.3 \%, 48.1 \%$ and $55.0 \%$ of the night, dawn, day and dusk periods, respectively $\left(\chi^{2}=1055, p<0.0001\right)$, with the modal depth for time spent being 10-20 $\mathrm{m}$ at night and dawn and 20-30 $\mathrm{m}$ in the day and at dusk. For H3, deeper dives comprised $50.4 \%, 55.0 \%, 59.2 \%$ and $55.0 \%$ for night, dawn, day and dusk, respectively $\left(\chi^{2}=357, p<0.0001\right)$,

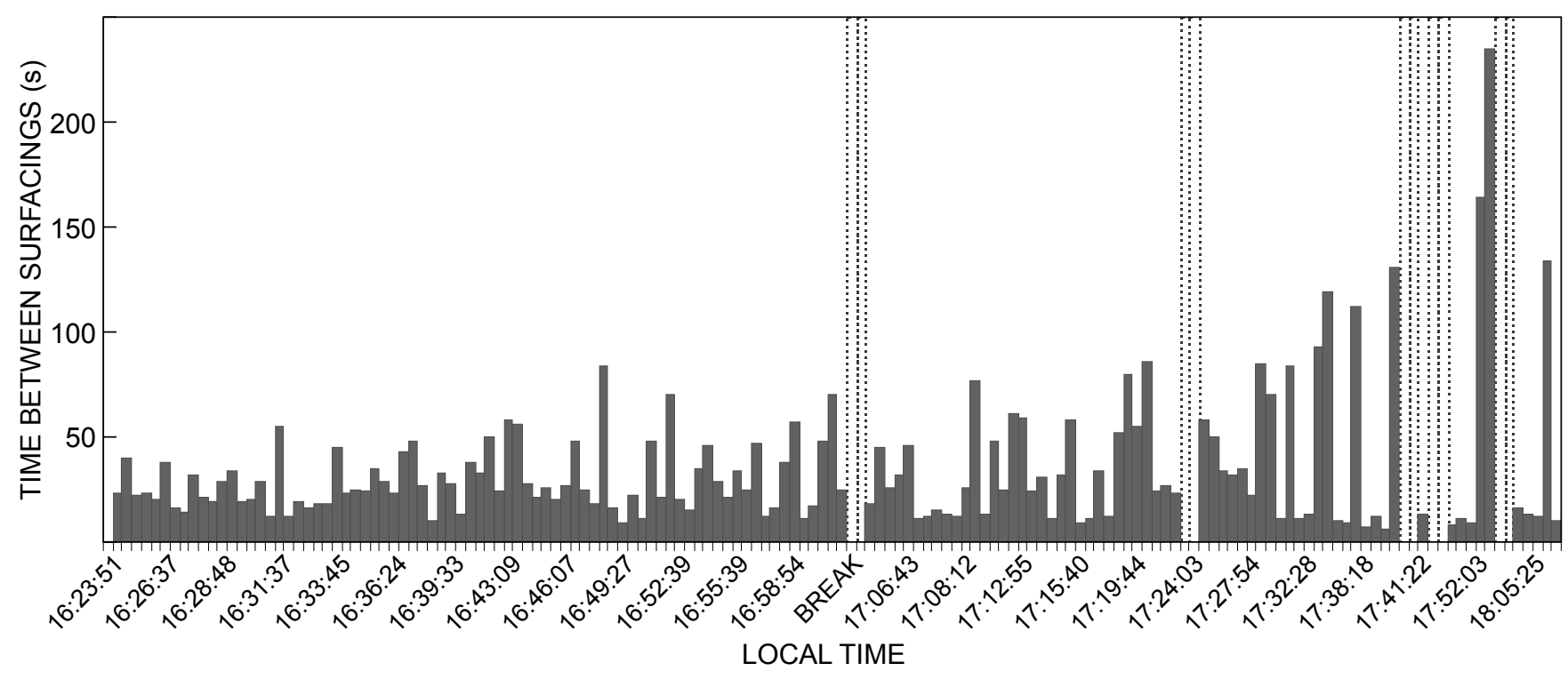

Figure 3: Surfacing times recorded from VHF signals received from Heaviside's dolphin H2 off the west coast of South Africa, 24 March 1997. Dotted lines indicate periods when signal may have been lost

Table 4: Surfacing intervals for Heaviside's dolphin H2 recorded by VHF on 24 March 1997

\begin{tabular}{|c|c|c|c|c|c|c|}
\hline \multirow{2}{*}{ Surfacing interval } & \multicolumn{6}{|c|}{ Period } \\
\hline & $16: 24-16: 39$ & $16: 40-16: 54$ & $16: 55-17: 09$ & $17: 10-17: 24$ & $17: 25-17: 39$ & $17: 40-18: 08$ \\
\hline $\bar{n}$ & 34 & 30 & 26 & 20 & 20 & 12 \\
\hline Range (s) & $10-55$ & $9-84$ & $11-77$ & $9-86$ & $6-119$ & $8-235$ \\
\hline Mean (s) & 25.9 & 32.4 & 29.5 & 38.1 & 43.7 & 63 \\
\hline SE (s) & 1.9 & 3.3 & 3.7 & 5.1 & 8.4 & 23.1 \\
\hline $\mathrm{CV}$ & 0.42 & 0.55 & 0.63 & 0.59 & 0.84 & 1.22 \\
\hline
\end{tabular}


with the modal depth for time spent being 10-20 $\mathrm{m}$ for dawn and day and 20-30 $\mathrm{m}$ for dusk and night (Figure 6).

\section{Discussion}

Although there has been a previous study of Heaviside's dolphin movements and home range size (Elwen et al. 2006), this study is the first to obtain these data for a male and represents the first time that the diving behaviour of
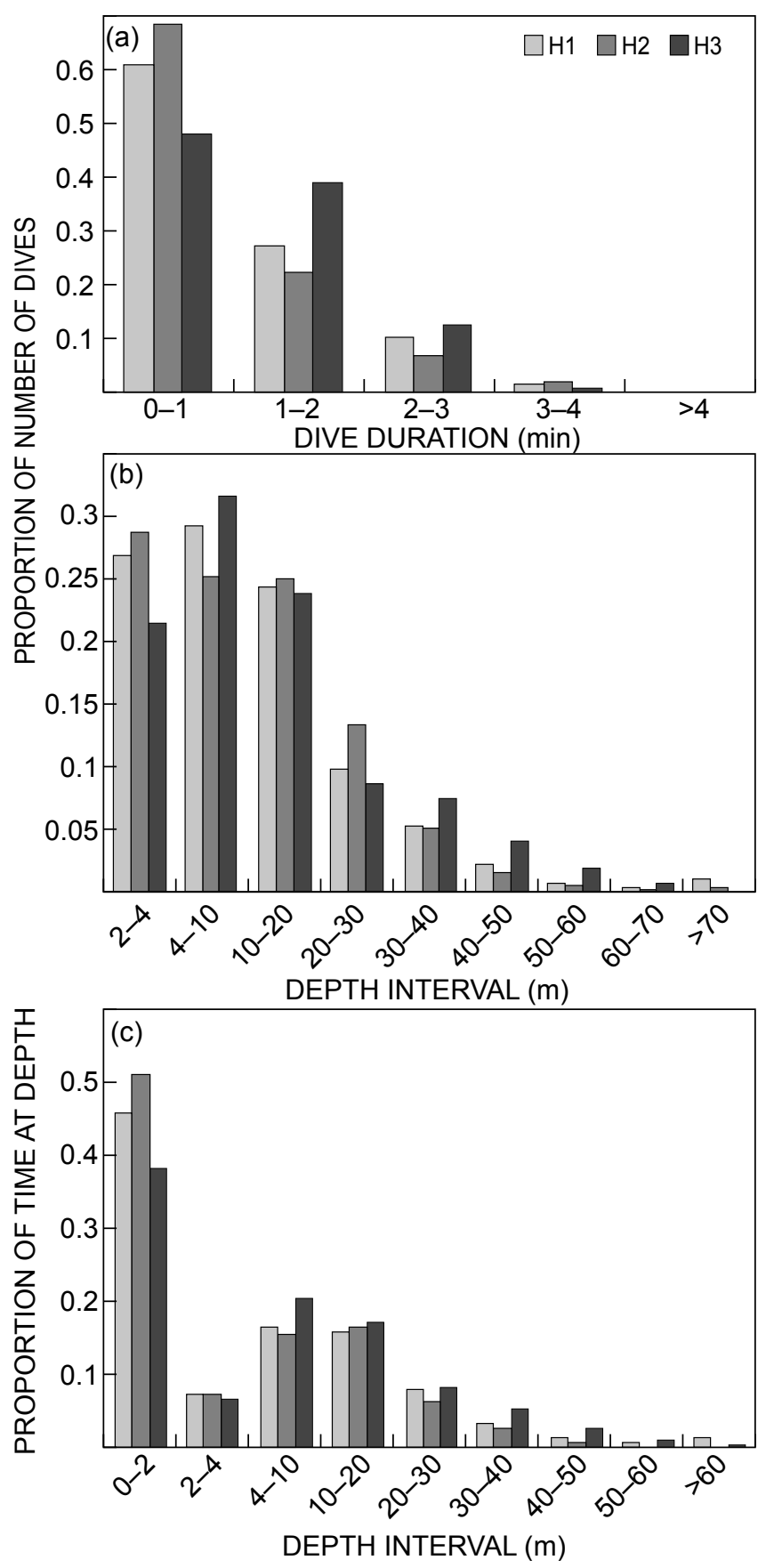

Figure 4: Proportional frequency of (a) dive durations, (b) maximum dive depths and (c) time spent at different depths by three Heaviside's dolphins $(\mathrm{H} 1, \mathrm{H} 2$ and $\mathrm{H} 3)$ satellite-tagged off the west coast of South Africa
Heaviside's dolphins has been monitored. Additionally, the duration of tracking was longer (51-130 days) than in the previous study (11-54 days) and was conducted at a different time of year (February-June vs August-January). Hence, our study provides important new information on this poorly understood species.

Adequate data were collected for dolphins $\mathrm{H} 1$ and $\mathrm{H} 3$ for detailed analyses, but the paucity of results and poor quality of the data for $\mathrm{H} 2$ limited analysis. With regard to $\mathrm{H} 2$, we suspect that malfunction of the transmitter was the most likely cause, but cannot entirely rule out unusual surfacing behaviour, although it appeared normal during the two occasions when the animal was followed.

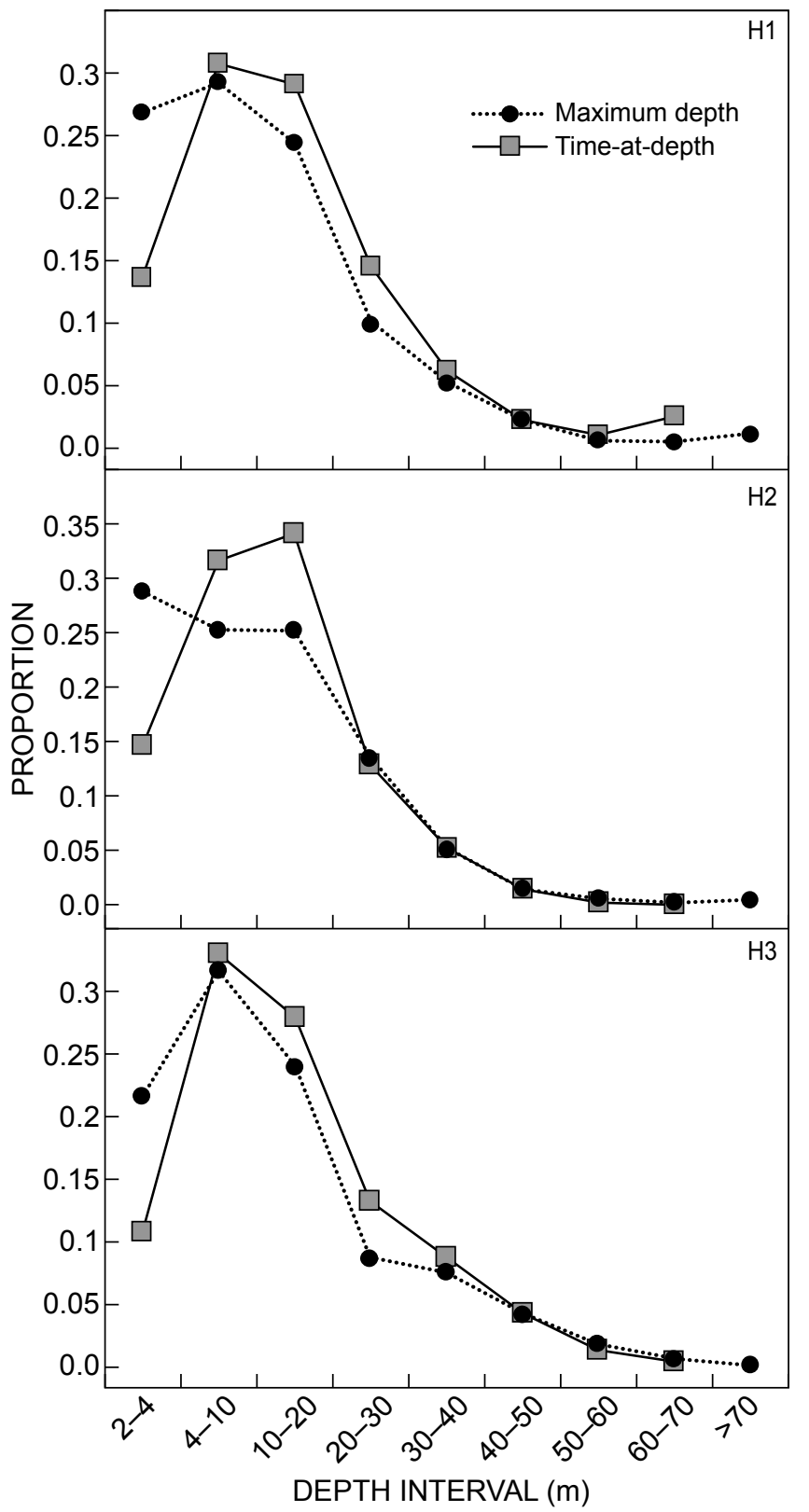

Figure 5: Distributions of maximum dive depths and time-at-depth over nine depth intervals for three Heaviside's dolphins ( $\mathrm{H} 1, \mathrm{H} 2$ and $\mathrm{H} 3$ ) satellite-tagged off the west coast of South Africa 
Table 5: Results of ANOVA for mean number of deep dives ( $>4 \mathrm{~m}$ ) and mean maximum depth per period of day in two Heaviside's dolphins satellite-tagged off the west coast of South Africa, where $n=$ the number of respective periods

\begin{tabular}{|c|c|c|c|c|c|c|c|c|c|c|c|c|}
\hline \multirow{2}{*}{ Period } & \multicolumn{6}{|c|}{ Mean number of deep dives (>4 m) } & \multicolumn{6}{|c|}{ Mean maximum depth $(\mathrm{m})$} \\
\hline & \multicolumn{3}{|c|}{$\mathrm{H} 1$} & \multicolumn{3}{|c|}{$\mathrm{H} 3$} & \multicolumn{3}{|c|}{$\mathrm{H} 1$} & \multicolumn{3}{|c|}{$\mathrm{H} 3$} \\
\hline Dawn & 35 & $142.5(5.3)$ & vs Day** & 46 & $165.2(5.2)$ & vs Dusk ${ }^{* *}$ & 35 & $16.5(1.1)$ & & 46 & $18.5(1.2)$ & vs Day** \\
\hline $\bar{F}$ & & $17.1^{\star \star \star \star}$ & & & $25.4^{\star \star}$ & & & $4.07^{* \star}$ & & & $30.03^{*}$ & \\
\hline
\end{tabular}

$\left.{ }^{*} p<0.05 ;{ }^{* *} p<0.01 ;{ }^{* * *} p<0.0001\right)$

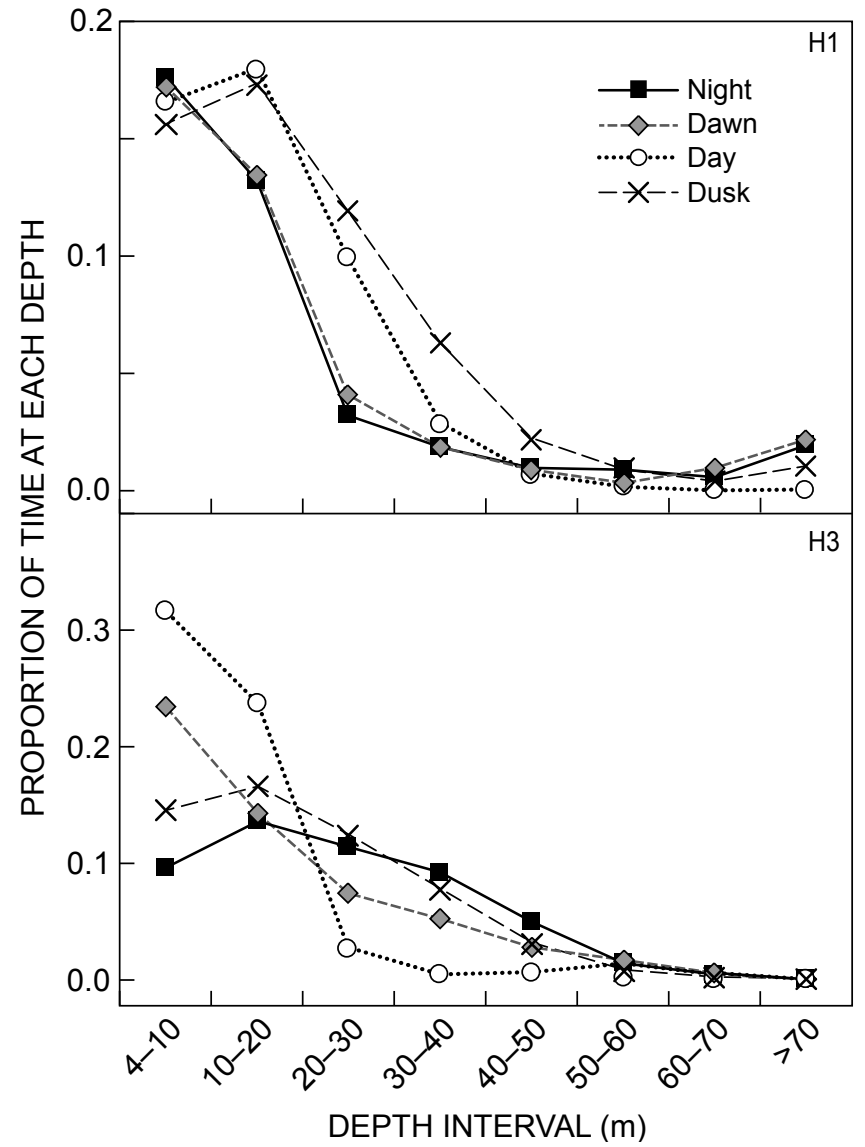

Figure 6: Time spent at depth on deep dives during night, dawn, day and dusk by two Heaviside's dolphins ( $\mathrm{H} 1$ and $\mathrm{H} 3)$ satellite-tagged off the west coast of South Africa

The saddles were designed to fall off after approximately 60 days, and the termination of signals from $\mathrm{H} 1$ and $\mathrm{H} 3$ after 51 and 73 days seemed consistent with this. However, the fact that $\mathrm{H} 2$ continued to transmit for 130 days made it clear that the release system was not completely reliable. This was confirmed on 17 March 2000 when H3 was seen by one of us (PBB) and photographed in Elands Bay with a damaged dorsal fin, the animal being recognised from its freeze brand (Figure 7). The damage to the fin showed that the transmitter had not released as intended, but had migrated posterio-dorsally through the fin by water pressure. The animal, however, appeared in good health 991 days after the last transmission had been received and within $13 \mathrm{~km}$ of its tagging site. Nevertheless, this evidence underlines the importance of appropriate design and testing of such release mechanisms.

The fact that locations were received almost exclusively between midnight and 09:00 to the virtual exclusion of the rest of the day was a matter for concern, as was the low number of locations per day (mean $=2.5$ for $\mathrm{H} 1$ and $\mathrm{H} 3$ ). The explanation for the very limited reception period lies in the fact that we restricted the instruments to transmit a maximum of 300 messages $\mathrm{d}^{-1}$ to conserve battery life. Theoretically, $\mathrm{H} 1$ and $\mathrm{H} 2$ could have transmitted a maximum of 90 messages $\mathrm{h}^{-1}$ and $\mathrm{H} 3180$ messages $\mathrm{h}^{-1}$. In practice, this was not likely to happen, but to exhaust the limit of 300 messages in the $9 \mathrm{~h}$ period from midnight to 09:00 would require an average of only about 33 messages $h^{-1}$. This was undoubtedly the reason for the concentration of messages early in the day.

The limited number of transmissions also explains the low number of daily locations for each dolphin. During the period between midnight and 09:00, there was an average of two good passes by Satellite $D$ and one good pass by Satellite $\mathrm{J}$, a good pass being defined as one during which the elevation of the satellite was optimal for receiving messages. Because the satellite can fix only one location per orbit and there was a total of only three good satellite passes within the $9 \mathrm{~h}$ period, it follows that there could be a maximum of only three locations per day per dolphin.

This restriction of the diurnal reception of location data could potentially influence estimates of home range if there are regular onshore-offshore movements on a daily basis, as shown by Elwen et al. (2006). However, the distance from shore of the five individuals illustrated in Elwen et al. (2006) suggests that for the $9 \mathrm{~h}$ after midnight the maximum distance offshore (illustrated as the 95th quartile) was greater than or similar to that for the rest of the day in three individuals, greater than that in all but two hourly intervals in another, and in only one individual were the majority of maximum distances in the latter half of the day greater than in the first $9 \mathrm{~h}$. In addition, the 


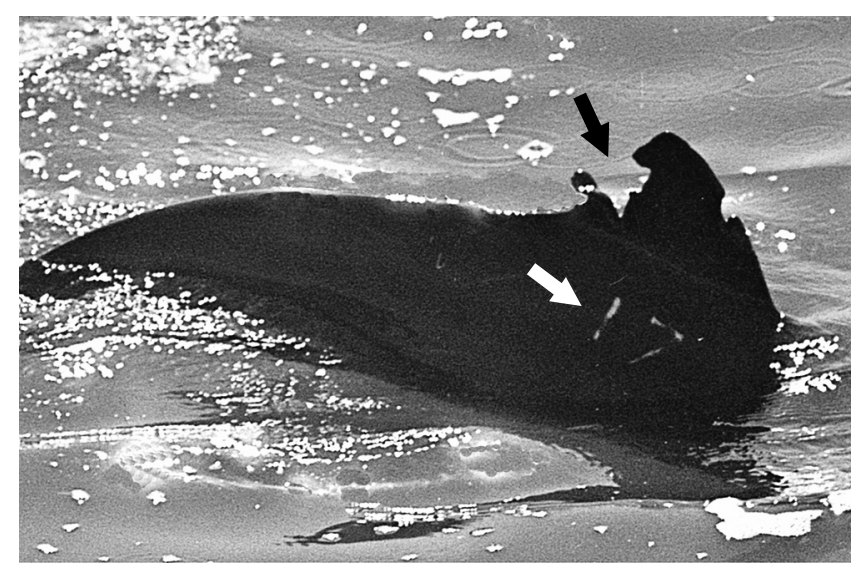

Figure 7: Female Heaviside's dolphin (H3) photographed 2 y 11 mo after tagging on the South African coast, showing damage caused by the tag migrating out of the dorsal fin (black arrow) rather than being released as planned. Note freeze brand ' 17 ' applied at the time of tagging (white arrow)

maximum distances offshore recorded for $\mathrm{H} 1$ and $\mathrm{H} 3$ (32.9 and $22.8 \mathrm{~km}$ ) are of a similar order to the 95th quartiles (16-30 km) shown for the five tagged dolphins in Elwen et al. (2006). Therefore, we conclude that, if there was an effect of the restricted daily temporal coverage on estimation of home range size, it was minor.

The home ranges of Heaviside's dolphins estimated here ranged from 670 to $2300 \mathrm{~km}^{2}$, depending on the estimation method. As was expected, given the tendency for the MCP method to overestimate range size, greater values were obtained with this method than with local convex hull isopleths. Under these circumstances, we believe that using $100 \% \alpha$-LoCoH isopleths was the most appropriate method of determining home range size for Heaviside's dolphin.

Heaviside's dolphin home ranges obtained here were broadly consistent with those previously reported for this species by Elwen et al. (2006), where 100\% MCP home ranges ranged between 1000 and $2400 \mathrm{~km}^{2}$ and $\mathrm{k}-\mathrm{LoCoH}$ $100 \%$ isopleths from 876 to $1990 \mathrm{~km}^{2}$. However, the home range for $\mathrm{H} 3$ as estimated from $100 \% \mathrm{LoCoH}$ was $23 \%$ smaller than the smallest estimate by Elwen et al. (2006), although it represented an effective monitoring period of 71 days, $29 \%$ longer than any monitored by Elwen et al. (2006). This animal was a female, believed to be sexually mature from its body weight, and equivalent in size to some of the largest tagged in the earlier study that had home ranges estimated using $100 \% \mathrm{LoCoH}$ - almost 2-3 times larger. Its home range as estimated using $100 \% \mathrm{MCP}$, although within the range given by Elwen et al. (2006), was also only some $43-60 \%$ of the home ranges estimated for females of a similar size. The sighting of this animal in March 2000 was also within its core area as defined in 1997 from MCP and within the $80 \%$ isopleths from $\mathrm{LoCoH}$. Such a restricted home range had its equivalent in an analysis of home range characteristics for 20 photographically identified Hector's dolphins Cephalorhynchus hectori off New Zealand, where the most frequently sighted individual (a female) had the smallest kernel estimate of alongshore home range $(13.6 \mathrm{~km})$ and was considered anomalous (Rayment et al. 2009).
If the size of the home range represents the relative predictability of resources within it (Gowans et al. 2007), then presumably dolphin $\mathrm{H} 3$ had particular access or had developed an optimal strategy to exploit those resources. Research trawl catches over the period 1990-2001 of juvenile shallow-water hake Merluccius capensis, a principal prey item of Heaviside's dolphin, showed an especially high density offshore from Elands Bay which is at the southern end of the range of $\mathrm{H} 3$ (Elwen et al. 2010). Ready access to this resource may partly explain the limited movements shown by this individual.

Comparison of the home range estimates with those in Elwen et al. (2006) broadens our knowledge of the biology of Heaviside's dolphin, in that (1) estimates from late summer and autumn were similar to those of late winter and spring, (2) there was no sign of the home range size increasing if the monitoring period was extended from a maximum of 54 to 71 days, and (3) the only male so far studied (albeit probably sexually immature) had a home range that was comparable with those of most of the females so far monitored.

Table 6 lists 13 studies of six species of small coastal cetaceans that have resulted in estimations of individual home range (excluding those of longshore range that are intrinsically underestimates). The estimations include those for two Heaviside's dolphin congeners, C. hectori and $C$. eutropia. Based on the data from three satellite-tagged $C$. hectori, Stone et al. (2005) provided estimates of their mean activity radius $(10.35-13.77 \mathrm{~km})$, but also illustrated MCP and Anderson Fourier home ranges without providing the results. Visually, these were obviously larger than the ranges calculated from the mean activity radius that excluded a large number of locations received for each individual. The Anderson Fourier ranges in particular appear to be more realistic representations of the distribution of locations received and, unlike the MCP ranges, avoided including swathes of landmass. Consequently, we have computed these ranges from the Stone et al. (2005) data, using scales of longitude and latitude provided with their figures (Table 6). Heinrich (2006) provided estimates of home range for $C$. eutropia based on resightings of naturally marked individuals, restricting the analyses to individuals seen at least 20 times. No estimates of home range for the congener C. commersonii have been published, but an individual is known to have ranged over a distance of $250 \mathrm{~km}$ (Coscarella et al. 2011).

The estimates of home range for $C$. heavisidii and $C$. hectori are larger than those for most of the species/ populations listed in Table 6, the only exceptions being the values for Tursiops truncatus off Queensland and the Azores and Phocoena phocoena. Confounding this comparison is the fact that two of these exceptions were the only other ones for which the data were collected via satellite tracking, as opposed to photo identification or radio tracking. Unless carefully planned, the latter techniques are likely to lead to underestimation of home range, given that individuals moving outside the study area will not be located and, in the case of photo identification, if the population is too large, the probability of resighting will be low, with a corresponding scarcity of locations. These considerations also mean that the methodology is applied to extreme nearshore populations as opposed to the wider-ranging 
Table 6: Estimates of home range in small cetaceans ( $n=$ number of individuals)

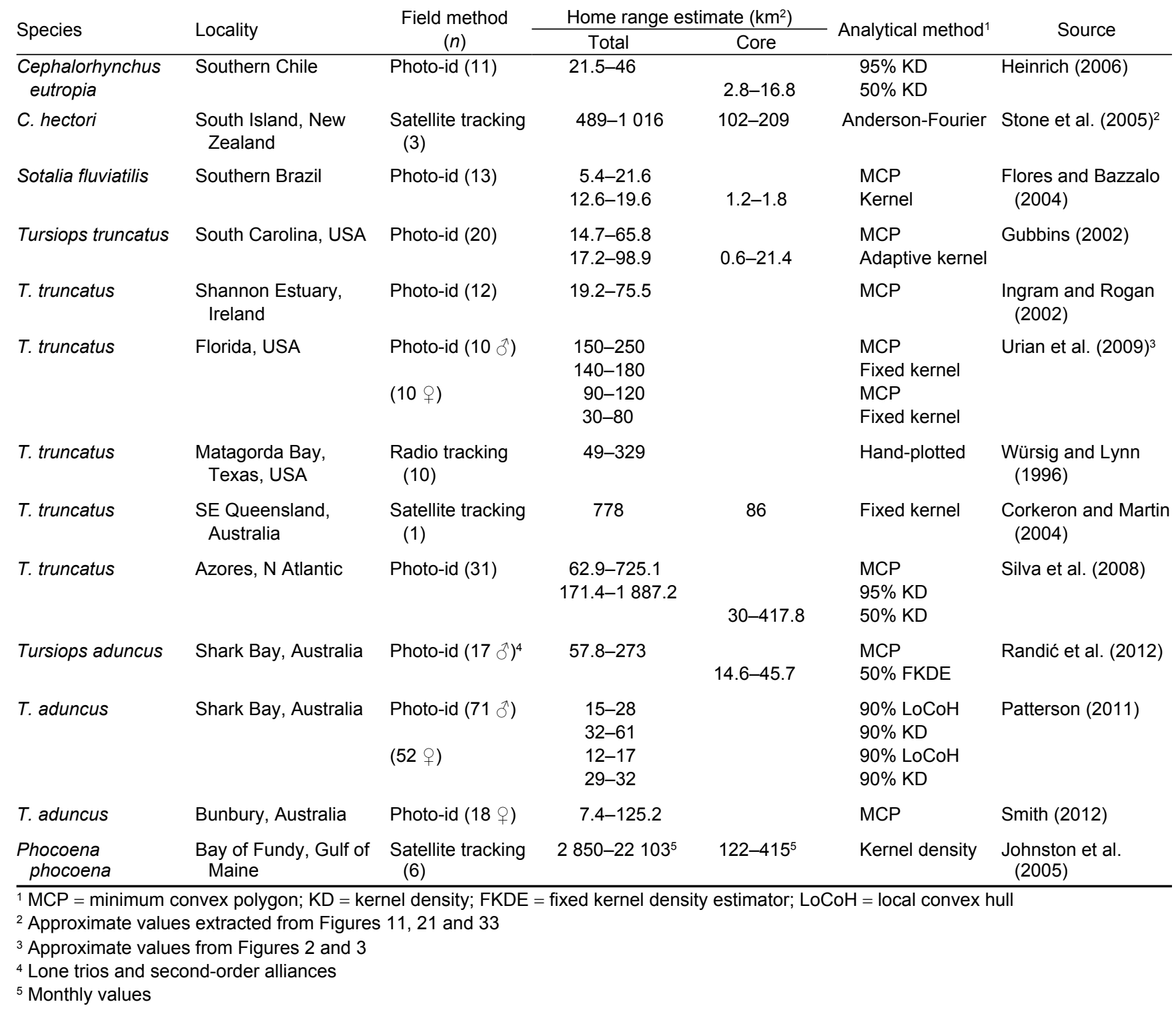

pelagic species. Satellite tracking does not suffer from these drawbacks, but unless the data are carefully vetted, location inaccuracy can lead to overestimation of home range. Cost also usually limits the number of individuals that can be tagged, so that their representativeness is open to question (Hooker and Baird 2001). No agreement has been reached on the most appropriate model (or its parameters) with which to measure home range, so complicating comparisons even further. At this stage, all that can be concluded is that $C$. heavisidii (and possibly C. hectori) seem to have larger home ranges than inshore Tursiops, but how these relate to the home ranges of other - more pelagic - species is unclear, as is any biological significance of the difference. Being derived from a photo identification study, the smaller home range estimates for $C$. eutropia than for its two congeners are therefore more likely to reflect methodological rather than biological differences.
Although the home ranges shown for $\mathrm{H} 1$ and $\mathrm{H} 3$ barely overlapped, they formed part of a mosaic of overlapping ranges with the five dolphins tagged by Elwen et al. (2006; see their Figure 3), such that each of the seven dolphins' ranges overlapped with at least three others. Core areas were seemingly more discrete, with three individuals (including $\mathrm{H} 1$ ) being grouped around Stompneuspunt to the south, and three around Elands Bay (Figure 1) about $45 \mathrm{~km}$ to the north (with a fourth [H3] lying still farther north). The gap between the first two groups, however, corresponds to the protected head of St Helena Bay, where Heaviside's dolphin sightings are among the rarest on the coast south of $\sim 32^{\circ} \mathrm{S}$ (Elwen et al. 2010), and hence the degree of separation observed may be atypical. Core areas in each home range were adjacent to the coast, a pattern also seen in the five dolphins in Elwen et al. (2006), although some of the latter also showed smaller offshore areas of high use. 
This emphasises the importance of nearshore waters to the species, even if feeding has rarely been observed there.

Hooker and Baird (2001) discussed many of the limitations in studying diving behaviour from summary statistics such as those provided via satellite. These include the lack of information on behaviour during dives, or ascent and descent rates, ignorance of dive profiles and inability to investigate the correlation of dive depth and duration. Short-term changes in diving behaviour (such as might occur around dawn and dusk) can also be overlooked because of the long periods for which data are summarised. However, an opportunity to monitor the surfacing intervals of one dolphin using VHF tracking provided an interesting example of such behaviour at dusk (Figure 3, Table 4), suggesting the onset of diving interspersed with rapid recovery surfacings. Compared to data from time-depth recorders, such summary statistics provide a much coarser resolution of diving behaviour over time. Nevertheless, they do provide data suitable for examining whether there are differences in dive parameters between the four 6-hourly periods each day. In addition, determination of what constitutes a dive (rather than a submergence as part of a surfacing sequence) is needed for behavioural interpretation of the data: although the tags were programmed to register a submergence below $2 \mathrm{~m}$ as 'a dive', inspection of the time-at-depth data suggested that this depth was too shallow, and a more objective criterion of $4 \mathrm{~m}$ was used in the analysis.

Despite the limitations of the data, we conclude that both dolphins under study exhibited changes in surfacing and diving behaviour with time of day, but that these were not entirely consistent between individuals. Both individuals made their shallowest dives during the day and their deepest at dusk or during the night, but whereas $\mathrm{H} 1$ had the highest incidence of deep dives at night and lowest during the day, $\mathrm{H} 3$ had a higher incidence of deep dives at dawn and during the day than at dusk or during the night. The degree of interperiod difference was also greater in $\mathrm{H} 3$ than in $\mathrm{H} 1$. Even though the majority of our location data only span the period midnight to 09:00, so that we cannot be sure where the animals spent the remainder of the day, the daily pattern of diving behaviour observed would be consistent with the animals being farther offshore at dusk and during the night than during the day (as described by Elwen et al. 2006).

The movements and diving behaviour of Heaviside's dolphin may be determined largely by the diel, vertical migration of its prey, with shallow-water hake being the main prey item (Sekiguchi et al. 1992). Midwater- and bottom trawling and acoustic observations on the west coast of South Africa show that whereas large hake $(20 \mathrm{~cm}$ or more) were caught only on or close to the bottom throughout the day and night, juvenile $M$. capensis ( $<20 \mathrm{~cm}$ long) made individual foraging migrations throughout the water column at night (Pillar and Barange 1993, 1995). Sekiguchi et al. (1992) found that the hake eaten by Heaviside's dolphin along the southern African coast ranged from 4.9 to $28.6 \mathrm{~cm}$ in length, with a mean of $19.5 \mathrm{~cm}$, but $65 \%$ were over $20 \mathrm{~cm}$ so the species appears to be exploiting both juvenile and adult hake. Hence deep-diving during the daytime may facilitate the exploitation of fish distributed close to the sea floor in relatively shallow water, whereas as the juvenile hake come off the bottom at dusk and during the night, prey availability to surface predators such as the dolphins increases and enables them to forage farther offshore.

Acknowledgements - We thank the following people for providing technical and practical expertise and assistance during the capture and handling of the dolphins: PG Kotze, S Swanson, M Thornton, $\mathrm{J}$ de Goede, $\mathrm{H}$ Visser, M Patterson and $L$ Rea. We also thank veterinarians $\mathrm{P}$ Koen, $\mathrm{J}$ Wessels, $\mathrm{V}$ Thom and $\mathrm{R}$ Borrowdale, and veterinary nurse $S$ Corprel, for supervision and assistance with veterinary care of the dolphins during capture and handling. We thank BS Stewart for the provision of satellite tracking software and insightful discussions, and Kevin $\mathrm{Ng}$ (Wildlife Computers Ltd) who assisted greatly in explaining tag characteristics for data collection, storage and transmission. Permission to cite data from a contract report was kindly provided by Greg Stone (Moore Center for Science and Oceans, Conservation International, USA). We are indebted to the South African Department of Environmental Affairs and Tourism for providing the RV Malagas // for the study, and the captain, officers and crew were most helpful during the three cruises involved in this study. This paper was substantially improved by the comments of numerous reviewers. PBB acknowledges the support of the National Research Foundation, De Beers Marine (Pty) Ltd and the World Wide Fund for Nature, South Africa. KS acknowledges the support of the Nature Conservation Society of Japan (Pro-Natura Fund). All fieldwork was undertaken in terms of permits issued to PBB and MAM under the South African Sea Fishery Act (Act No. 12 of 1988).

\section{References}

Asper ED. 1975. Techniques of live-capture of smaller Cetacea. Journal of the Fisheries Research Board of Canada 32: 191-196.

Best PB. 2007. Whales and dolphins of the southern African subregion. Cape Town: Cambridge University Press.

Best PB, Abernethy RB. 1994. Heaviside's dolphin Cephalorhynchus heavisidii (Gray, 1828). In: Ridgway SH, Harrison R (eds), Handbook of marine mammals, Volume 5: the first book of dolphins. San Diego: Academic Press. pp 289-310, 415-416.

Burgman MA, Fox JC. 2003. Bias in species range estimates from minimum convex polygons: implications for conservation and options for improved planning. Animal Conservation 6: 19-28.

Corkeron PJ, Martin AR. 2004. Ranging and diving behaviour of two 'offshore' bottlenose dolphins, Tursiops sp., off eastern Australia. Journal of the Marine Biological Association of the UK 84: 465-468.

Coscarella MA, Gowans S, Pedraza SN, Crespo EA. 2011. Influence of body size and ranging patterns on delphinid sociality: associations among Commerson's dolphins. Journal of Mammalogy 92: 544-551.

Crawford RJM, Shannon LV, Pollock D. 1987. The Benguela ecosystem. Part IV. The major fish and invertebrate resources. Oceanography and Marine Biology - An Annual Review 25: 353-505.

Davis RW, Worthy G, Würsig B, Lynn SK, Townsend FL. 1996. Diving behavior and at-sea movements of an Atlantic spotted dolphin. Marine Mammal Science 12: 569-581.

Elwen SH, Best PB, Reeb D, Thornton M. 2009. Diurnal movements and behaviour of Heaviside's dolphins (Cephalorhynchus heavisidii), with some comparative data for dusky dolphins (Lagenorhynchus obscurus). South African Journal of Wildlife Research 39: 143-154.

Elwen S, Meÿer MA, Best PB, Kotze PGH, Thornton M, Swanson S. 2006. Range and movements of Heaviside's dolphins (Cephalorhynchus heavisidii), as determined by satellite-linked 
telemetry. Journal of Mammalogy 87: 866-877.

Elwen SH, Thornton M, Reeb D, Best PB. 2010. Near-shore distribution of Heaviside's (Cephalorhynchus heavisidii) and dusky dolphins (Lagenorhynchus obscurus) at the southern limit of their range in South Africa. African Zoology 45: 78-91.

Findlay KP, Best PB, Ross GJB, Cockcroft VG. 1992. The distribution of small odontocete cetaceans off the coasts of South Africa and Namibia. In: Payne AIL, Brink KH, Mann KH, Hilborn $\mathrm{R}$ (eds), Benguela trophic functioning. South African Journal of Marine Science 12: 237-270.

Flores PAC, Bazzalo M. 2004. Home ranges and movement patterns of the marine tucuxi dolphin, Sotalia fluviatilis, in Baia Norte, southern Brazil. Latin American Journal of Aquatic Mammals 3: 37-52.

Getz WM, Wilmers CC. 2004. A local nearest-neighbor convexhull construction of home ranges and utilization distributions. Ecography 27: 489-505.

Gowans S, Würsig B, Karczmarski L. 2007. The social structure and strategies of delphinids: predictions based on an ecological framework. Advances in Marine Biology 53: 195-294.

Gubbins C. 2002. Use of home ranges by resident bottlenose dolphins (Tursiops truncatus) in a South Carolina estuary. Journal of Mammalogy 83: 178-187.

Heinrich S. 2006. Ecology of Chilean dolphins and Peale's dolphins at Isla Chiloé, southern Chile. PhD thesis, University of St Andrews, Scotland, UK.

Hooker SK, Baird RW. 2001. Diving and ranging behaviour of odontocetes: a methodological review and critique. Mammal Review 31: 81-105.

Ingram SN, Rogan E. 2002. Identifying critical areas and habitat preferences of bottlenose dolphins Tursiops truncatus. Marine Ecology Progress Series 244: 247-255.

Irvine AB, Wells RS, Scott MD. 1982. An evaluation of techniques for tagging small odontocete cetaceans. Fishery Bulletin, US 80: 135-143.

Johnston DW, Westgate AJ, Read AJ. 2005. Effects of fine-scale oceanographic features on the distribution and movements of harbour porpoises Phocoena phocoena in the Bay of Fundy. Marine Ecology Progress Series 295: 279-293.

Kie JG, Baldwin JA, Evans CJ. 1996. CALHOME: a program for estimating animal home ranges. Wildlife Society Bulletin 23 : 342-344.

Mate BR. 1989. Satellite-monitored radio tracking as a method for studying cetacean movements and behaviour. Report of the International Whaling Commission 39: 389-391.

Mate BR, Nieukirk S, Mesecar R, Martin T. 1992. Application of remote sensing methods for tracking large cetaceans: North Atlantic right whales Eubalaena glacialis. Report No. 91-0069. US Department of the Interior, Minerals Management Service.

Mohr CO. 1947. Table of equivalent populations of North American small mammals. American Midland Naturalist 37: 223-249.

Odell DK, Asper ED. 1990. Distribution and movements of freezebranded bottlenose dolphins in the Indian and Banana Rivers, Florida. In: Leatherwood S, Reeves RR (eds), The bottlenose dolphin. San Diego: Academic Press. pp 515-540.

Patterson EM. 2011. Ecological and life history factors influence habitat and tool use in wild bottlenose dolphins (Tursiops sp.). PhD thesis, Georgetown University, Washington DC, USA.

Pillar SC, Barange M. 1993. Feeding selectivity of juvenile Cape hake Merluccius capensis in the southern Benguela. South African Journal of Marine Science 13: 255-268.

Pillar SC, Barange M. 1995. Diel feeding periodicity, daily ration and vertical migration of juvenile Cape hake off the west coast of South Africa. Journal of Fish Biology 47: 753-768.

Randić S, Connor RC, Sherwin WB, Krützen M. 2012. A novel mammalian social structure in Indo-Pacific bottlenose dolphins (Tursiops sp.): complex male alliances in an open social network. Proceedings of the Royal Society B 279: 3083-3090.

Rayment W, Dawson S, Slooten E, Bräger S, Du Fresne S, Webster T. 2009. Kernel density estimates of alongshore home range of Hector's dolphins at Banks Peninsula, New Zealand. Marine Mammal Science 25: 537-556.

Reeves RR, Crespo EA, Dans S, Jefferson TA, Karczmarski L, Laidre K, O'Corry-Crowe G, Pedraza S, Rojas-Bracho L, Secchi ER, Slooten E, Smith BD, Wang JY, Zhou K. 2013. Cephalorhynchus heavisidii. IUCN Red List of Threatened Species. Version 2013.1. Available at www.iucnredlist.org.

Rohr JJ, Fish FE, Gilpatrick JW. 2002. Maximum swim speeds of captive and free-ranging delphinids: critical analysis of extraordinary performance. Marine Mammal Science 18: 1-19.

Seaman DE, Millspaugh JJ, Kernohan BJ, Brundige GC, Raedeke KJ, Gitzen RA. 1999. Effects of sample size on kernel home range estimates. Journal of Wildlife Management 63: 739-747.

Sekiguchi K, Klages NTW, Best PB. 1992. Comparative analysis of the diets of smaller odontocete cetaceans along the coast of southern Africa. In: Payne AlL, Brink KH, Mann KH, Hilborn R (eds), Benguela trophic functioning. South African Journal of Marine Science 12: 843-861.

Silva MA, Prieto R, Magalhães S, Seabra MI, Santos RS, Hammond PS. 2008. Ranging patterns of bottlenose dolphins living in oceanic waters: implications for population structure. Marine Biology 156: 179-192.

Smith H. 2012. Population dynamics and habitat use of bottlenose dolphins (Tursiops aduncus), Bunbury, Western Australia. PhD thesis, Murdoch University, Australia.

Stewart BS, Leatherwood S, Yochem PK, Heide-Jorgensen MP. 1989. Harbor seal tracking and telemetry by satellite. Marine Mammal Science 5: 361-375.

Stone G, Hutt A, Duignan P, Teilmann J, Cooper R, Geschke K, Yoshinaga A, Russell K, Baker A, Suisted R, Baker S, Brown J, Jones G, Higgins D. 2005. Hector's dolphin (Cephalorhynchus hectori hectori) satellite tagging, health and genetic assessment project. Final report. Submitted to the Department of Conservation (DOC), Auckland Conservancy, in fulfilment of a contract to the New England Aquarium, Central Wharf, Boston, Massachusetts

Tanaka S, Takao K, Kato N. 1987. Tagging techniques for bottlenose dolphins, Tursiops truncatus. Nippon Suisan Gakkaishi 53: 1317-1325

Urian KW, Hofmann S, Wells RS, Read AJ. 2009. Fine-scale population structure of bottlenose dolphins (Tursiops truncatus) in Tampa Bay, Florida. Marine Mammal Science 25: 619-638.

Vincent C, McConnell BJ, Ridoux V, Fedak MA. 2002. Assessment of Argos location accuracy from satellite tags deployed on captive gray seals. Marine Mammal Science 18: 156-166.

White NA, Sjöberg M. 2002. Accuracy of satellite positions from free-ranging grey seals using ARGOS. Polar Biology 25: 629-631.

Witt MJ, Åkesson S, Broderick AC, Coyne MS, Ellick J, Formia A, Hays GC, Luschi P, Stroud S, Godley BJ. 2010. Assessing accuracy and utility of satellite-tracking data using Argos-linked Fastloc-GPS. Animal Behaviour 80: 571-581.

Würsig B, Lynn SK. 1996. Movements, site fidelity, and respiration patterns of bottlenose dolphins on the Central Texas Coast. NOAA Technical Memorandum NMFS-SEFSC-383. 